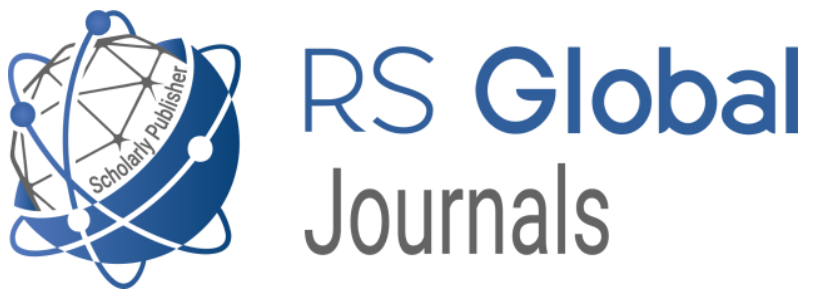

Scholarly Publisher

RS Global Sp. z O.O.

ISNI: 0000000484952390

Dolna 17, Warsaw, Poland 00-773

Tel: +48226022703

Email: editorial_office@rsglobal.pl

JOURNAL International Journal of Innovative Technologies in Social Science

p-ISSN

$2544-9338$

e-ISSN

2544-9435

PUBLISHER

RS Global Sp. z O.O., Poland

ARTICLE TITLE

УМОВИ ЗБЕРЕЖЕННЯ ФОНОДОКУМЕНТІВ В АРХІВІ

ARTICLE THLE

НАЦІОНАЛЬНОЇ СУСПІЛЬНОЇ ТЕЛЕРАДІОКОМПАНІЇ УКРАЇНИ

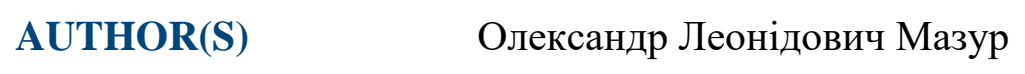

Oleksandr Mazur. (2021) Conditions for Preservation of Sound Documents in the Archives of the National Public Television and

ARTICLE INFO Radio Company of Ukraine. International Journal of Innovative Technologies in Social Science. 3(31). doi:

10.31435/rsglobal_ijitss/30092021/7675

DOI

https://doi.org/10.31435/rsglobal_ijitss/30092021/7675

RECEIVED

29 July 2021

ACCEPTED

07 September 2021

PUBLISHED

10 September 2021

LICENSE

This work is licensed under a Creative Commons Attribution

4.0 International License.

(C) The author(s) 2021. This publication is an open access article. 


\title{
УМОВИ ЗБЕРЕЖЕННЯ ФОНОДОКУМЕНТІВ В АРХІВІ НАЦІОНАЛЬНОЇ СУСПІЛЬНОЇ ТЕЛЕРАДІОКОМПАНІЇ УКРАЇНИ
}

\author{
Олександр Леонідович Мазур, аспірант, Національна академія керівних кадрів культури і \\ мистецттв, м. Київ, Украӥна, ORCID ID: https://orcid.org/0000-0003-0763-3436
}

DOI: https://doi.org/10.31435/rsglobal_ijitss/30092021/7675

\section{ARTICLE INFO}

Received 29 July 2021

Accepted 07 September 2021

Published 10 September 2021

\section{KEYWORDS}

Archive, Audio Records, Storage, Music, Digitization, Radio, Service, Phonostorage, Public Television and Radio Company of Ukraine.

\begin{abstract}
The article describes the basic principles of the archival fund of sound recordings of the National Public Television and Radio Company of Ukraine, the principles of their acquisition, storage, as well as communication aspects of the funds. The process of transferring phonograms of own production to archives is described. The peculiarities of the organization of archival subdivisions of JSC "NSTU" of the Central Directorate "Ukrainian Radio" and the conditions of preservation of musical sound documents as a part of the funds of radio companies are described. It is indicated in which premises the stock phonograms are stored, the conditions of their storage and the types of available media. The procedure for issuing and circulation of sound documents, types of media on which information of the appropriate type is stored, the number of storage units, regulatory conditions regarding temperature and humidity of air, which are installed in storage and supported by regulatory documents. The course of digitization processes is described and the prospects for migration of audio documents to the latest audio formats are outlined.
\end{abstract}

Citation: Oleksandr Mazur. (2021) Conditions for Preservation of Sound Documents in the Archives of the National Public Television and Radio Company of Ukraine. International Journal of Innovative Technologies in Social Science. 3(31). doi: 10.31435/rsglobal_ijitss/30092021/7675

Copyright: (C) 2021 Oleksandr Mazur. This is an open-access article distributed under the terms of the Creative Commons Attribution License (CC BY). The use, distribution or reproduction in other forums is permitted, provided the original author(s) or licensor are credited and that the original publication in this journal is cited, in accordance with accepted academic practice. No use, distribution or reproduction is permitted which does not comply with these terms.

Вступ. На сьогоднішній день актуальності набуває питання функціонування архівних фондів Національної Суспільної Телерадіокомпанії України, як таких, що на сьогоднішній день ще недостатньо досліджені, а також соціальна і комунікаційна роль яких в суспільстві та культурному середовищі повністю на даний момент ще не розкрита.

Мета. Метою даного дослідження виступає розкриття принципів діяльності та накопичення масиву інформації про роботу архівних фондів Національної Суспільної Телерадіокомпанії України, що зберігають у своїх сховищах фонограмні документи, які за своїм призначенням розраховані для трансляції на державному радіо України.

Матеріали та методи дослідження. При проведенні дослідження використовувалися загальнонаукові та спеціальні методи. Матеріалами для проведення даного дослідження слугувала наявна в архівних фондах НСТУ службова документація, безпосередній доступ дослідника до архівних сховищ, картотеки, електронного каталогу та звітної документації, що використовується в роботі з прийняттям на зберігання, проведенням експертизи та обліком наявних одиниць зберігання.

Результати дослідження. До складу Національної радіокомпанії України входять три програми внутрішнього мовлення і програма Всесвітньої служби радіомовлення України [6]. Статус аудіовізуальних документів Національної радіокомпанії України тривалий час був невизначеним, їх віднесення до складу Національного Архівного Фонду не підкріплявся будьякими положеннями нормативно-правових, у тому рахунку підзаконних, актів. У зв'язку з цим компанія проводила незалежну політику в сфері відомчого зберігання радіопрограм, 
включаючи питання комплектування, експертизи цінності документів, їх довготривалого зберігання і знищення.

Формування радіофонду НРКУ як основного аудіовізуального архіву здійснювалося під впливом уявлень керівництва компанії i працівників галузі про практичну цінність аудіовізуальних документів як матеріальних об'єктів і ресурсу для подальшої діяльності компанії. У компанії та іiі архівах не було вироблено чіткої концепції експертизи цінності документів та комплектування архівів, у зв'язку з чим спостерігалися безпідставні знищення фонодокументів, а неодноразова реорганізація архівів компанії в підсумку призвела до формування різнорідного за складом, змістом та наукової цінності комплексу фонодокументів, відмітними рисами якого $є$ висока повторюваність інформації, наявність значного масиву копій документів 3 інших архівів. До речі, подібне становище було і в деяких інших радіоархівах центральних державних мовних компаній на пострадянській території [3, С. 32]. Основоположними критеріями при експертизі цінності документів у музичному радіофонді були можливість використання документів у діяльності компанії, а також правовий статус документа, тобто приналежність авторських i суміжних прав на музичну радіопрограму. У зв'язку з цим документи, права компанії на які обмежені терміном або іншими умовами, розглядалися як менш цінні, ніж інші групи; критерії наукової, історичної та культурної цінності не враховувалися при оцінці документів, на відміну від практики державних архівів [2].

Фонотека НСТУ забезпечує повний цикл зберігання і доступу до використання фонограм. У фонотеці (аудіо-архіві) Українського радіо зберігаються фонограми на різних носіях: магнітній плівці, міні-дисках (MD) та компакт-дисках (CD/DVD). Це - найбільше і найповніше зібрання національної аудіо-спадщини. За структурою аудіоархів УР складається з двох підрозділів: а) Фондова фонотека (постійне, довічне зберігання); б) Фонотека тимчасового зберігання (для передач мовлення; записів, що потребують подальшого опрацювання, - скажімо, трансляцій концертів, вистав тощо, перезаписи зі сторонніх носіїв тощо). Термін зберігання визначають відповідні редакції, що здійснюють ці записи). В окремих випадках особливо цінні (за критеріями унікальності, історичності) фонограми за рішенням керівництва підрозділів та художнього фонду можуть переводитися з тимчасового зберігання на постійне, фондове. Формування аудіо-фондів: відбувається 3 кількох джерел: а) фонограми виконань творів, а також передачі (програми) мовлення, створені самим Українським радіо; б) фонограми, що надійшли за обміном (до 1991 р. - 3 Всесоюзного радіо (Москва) та радіо союзних республік, коли УР було складовою Держтелерадіо СРСР; після 1995 р. - з Свропейської Мовної Спілки (Женева), членом якої стало УP); в) перезаписи (дублі фонограм) з носіїв авторів та/або виконавців творів, а також з LP, MK, CD, DVD, що були у вільному продажу.

Облік фонограм Фондової фонотеки НСТУ фіксується в інвентарних книгах, картковому та електронному каталогах. Кожна фонограма має максимально можливий опис, що включає: № наряду-замовлення на здійснення запису (ДКС); № зберігання у фонотеці, дані про авторів твору (у т. ч. обробки, перекладу, оркестровки, інсценівки, адаптації тощо); дані про виконавців (солістів, колективи, диригента/керівника, дійових осіб та виконавців ролей тощо); дані про відповідального редактора запису; дані про звукорежисера запису; хронометраж фонограми; дату запису.

Наряд-замовлення на здійснення запису є одночасно і паспортом фонограми, в якому фіксується також: дати початку та завершення запису, дата і № протоколу засідання художньої ради 3 прийому фондових записів, іiі рішення - 3 підписами голови, секретаря та членів художньої ради.

Інвентарні книги та карткові каталоги оформлюються відповідно до нормативів оформлення архівів (фонотек, бібліотек тощо).

Програмне забезпечення електронного каталогу передбачає гнучку систему розширення полів бази даних кожного об'єкту (приміром, під одним номером можуть бути необмежена кількість окремих фонограм творів, скажімо, запис концерту з багатьма номерами, або оперного спектаклю з фіксацією кожного окремого фрагменту).

Фонограми власного виробництва, які за рішенням художньої ради приймаються до фонду, надходять до фонотеки на постійне зберігання у трьох примірниках (оригінал і два дублі). «Оригінал» - це недоторканий фонодокумент, більшість 3 них у подальшому передаються на зберігання до Державного кінофотофоноархіву України ім. Г. Пшеничного (згідно із Законами України «Про Національний Архівний фонд» [9], №595-XIV «Про 
обов’язковий примірник документів» та № 867-V «Про внесення змін до статті 8 Закону України «Про обов'язковий примірник документів»), зберігаючи за УР право власності на них.

«Перший дубль фонограми» - це резервна копія оригіналу, який використовується лише для виготовлення другого дублю у разі його пошкодження, втрати тощо. «Другий дубль фонограми» - це основна робоча копія, 3 якою працюють усі користувачі (редактори, звукооператори тощо).

Згідно ПТЕ-82, частина II (радіомовлення) аудіофонди НСТУ зберігаються в 4 ізольованих сховищах відповідно до технічних норм. Сховище фондових фонограм, обладнане мобільними стелажами та має площу 47 кв.м., дозволяє зберігати на своїх полицях у змотаному вигляді плівку, поміщену у відповідного розміру упаковки (картонні коробки) (7 630 шт.), в яких змотано 31130 фонограм (до 40 хв. хронометражу у кожній упаковці). Метадані про всі фонограми заносяться у електронну картотеку - базу даних фонограм.

Пошук файлів в ЕК здійснюється за художніми (назва твору; творча особа - прізвище композитора, письменника, поета, автора обробки; виконавці- вокалісти, інструменталісти, актори; колективи - хори, оркестри, ансамблі тощо; керівник - художній керівник, диригент, хормейстер, режисер-постановник; музичний інструмент - найчастіше використовується для пошуку народних інструментів) та технічними (номенклатурний № - поточний номер магнітної плівки або CD; вид носія -магнітна плівка, CD; вид запису - моно, стерео; група зберігання музичні, літературні, документальні записи) характеристиками, а також за музичною тематикою (характер, форма, вид музики тощо). Паралельно ведеться картотека в картковому вигляді. Згідно замовлень редакційного персоналу фонограми подаються на сервер в цифровому форматі для використання у радіомовленні. Фонограми за межі відділу не виносяться. Матеріал, що необхідний для створення передач, прослуховується безпосередньо у відділі фонограм.

У фондах НСТУ міститься симфонічна, камерна, вокальна, оперна, балетна, сучасна, народна та популярна музика; вистави, радіовистави, вірші, казки, оповідання; документальні записи (голоси письменників, відомих людей; репортажі часів Другої світової війни) [10]. Фонограми власного виробництва за рішенням Художньої ради НСТУ надходять до відділу фонограм у трьох примірниках (оригінал і два дублі). Згідно із Законом України від 9 квітня 1999 p. № 595-XIV «Про обов’язковий примірник документів» та Законом України від 4 квітня 2007 р. № 867-V «Про внесення змін до статті 8 Закону України «Про обов’язковий примірник документів» один 3 примірників передається на безоплатній основі ЦДКФФА України ім. Г. Пшеничного. Передача аудіозаписів відбувається наступним чином: наприкінці поточного року державний архів дає запит про кількість фонограм, що Українське радіо повинно передати на постійне зберігання; списки фонограм затверджуються протоколом експертної комісії УР; підтвердженням прийому фонограм на постійне зберігання в державний архів $\epsilon$ «Акт прийманняпередавання», затверджений керівництвом архіву та УР. Станом на 1.01 .2015 року аудіофонди НСТУ, що становлять художню та історичну цінність починаючи з 1943 по 2015 рік нараховують - 95000 фонограм на магнітній стрічці та 9533 фонограми на 1312 компакт-дисках. 3 них власного виробництва (на магнітній стрічці та CD) 59150 фонограм, від інших виробників 35000 фонограм. За останні 5 років до фондового архіву НРКУ надійшло 3848 записів власних фонограм (з 1.07 .2011 р. по 1.01.2012 p. - 757. 2012 p. - 658, 2013 p. - 746, 2014 p. - 1099), протягом I кварталу 2015 р. - надійшло 588 власних записів). За даний період надійшло оригіналів - 276 дисків, I дублів - 175 дисків, копій I дублів - 244 диски, II дублів - 198 дисків, копій II дублів - 1599 дисків (з них 254 переведені до фонду, 1345 - цифрові копії).

Станом на 01.01.2021p. фондова фонотека НРКУ налічує

\begin{tabular}{|l|l|l|l|}
\hline \multicolumn{1}{|c|}{ вид носія } & $\begin{array}{c}\text { одиниці обліку } \\
\text { (номенклатурні №) }\end{array}$ & $\begin{array}{c}\text { одиниці зберігання } \\
\text { (назви) }\end{array}$ & хронометраж \\
\hline магнітна плівка & 71254 & 95448 & 9044 год. \\
\hline СД & 1291 & 9653 & 1294 год \\
\hline СД-МП (плівка втрачена) & 629 & 1015 & 177 год. \\
\hline цифрові копії (плівка зберігається) & & 48271 & 4963 год \\
\hline
\end{tabular}

До «Фонотеки тимчасового зберігання» надходять записи в одному примірнику. Облік фонограм ведеться в інвентарних книгах. Фіксація добового мовлення чотирьох каналів (УР-1, УР-2, УР-3 та RUI) архівуються на компакт-диски. Журнал розкладу передач міститься окремим файлом (в Excel) для кожного каналу. Фонотека тимчасового зберігання налічує 


\begin{tabular}{|l|l|l|}
\hline \multicolumn{1}{|c|}{ вид носія } & \multicolumn{1}{c|}{$\begin{array}{c}\text { одиниці обліку } \\
\text { (номенклатурні №) }\end{array}$} & \multicolumn{1}{c|}{ хронометраж } \\
\hline CD (нові надходження) & 905 & 1702 год \\
\hline CD (архівація добового мовлення) & 2146 & 103000 год. \\
\hline магнітна стрічка & 1506 & 1763 год \\
\hline міні-диски & 286 & 1363 год \\
\hline
\end{tabular}

Фонограми для використання у радіомовленні передаються в цифровому форматі згідно замовлень редакційного персоналу.

Якщо для збереження аудіофонду НСТУ за станом на 1.01 .2015 р. 3 магнітної стрічки оцифровано понад 28000 фонограм, то на 1 січня 2021 р. - вже понад 48000 фонограм.

Звукозаписи мають зберігатися в умовах, що забезпечують їх захист від пошкоджень, шкідливих впливів навколишнього середовища і виключають втрату документів. Постійне зберігання фонодокументів має здійснюватися в темряві. Всі види робіт з документами повинні проводитися при обмежених або технологічно необхідних рівнях освітлення. Температурновологісний режим в сховищах контролюється шляхом регулярного вимірювання параметрів повітря. Фонодокументи у сховищах розміщуються в порядку, що забезпечує їх комплексне зберігання відповідно з обліковими документами та уможливлює оперативний пошук. Порядок розташування документів в архіві визначається планом (схемою) їх розміщення. Устаткування 3 висувними частинами (ящиками, секціями, дверцятами) встановлюється за спеціальними нормами 3 урахуванням розмірів засобів зберігання. Усі звукозаписи мають зберігатися в спеціалізованому приміщенні у металевих шафах або пристосованих для цього сейфах. Фонодокументи розміщують на стелажах, в шафах з використанням коробок, папок, спеціальних футлярів, пакетів і т. П. відповідно до видів, форматів та інших зовнішніх особливостей звуконосіїв [13]. Так, магнітні стрічки страхового фонду і фонду користування повинні мати стандартні і захисні ракорди, намотуватися в рулон на сердечники і зберігатися в металевих коробках, фонодокументи на плоских плівкових або інших форматних носіях упаковують у конверти і касети і зберігають в коробках, папках, іншій упаковці. Місце зберігання музичних та інших (немузичних) фонодокументів визначає керівник радіоорганізації.

Забезпечення зберігання фонодокументів передбачає також підтримку оптимальних режимів зберігання носіїв звукозапису. Якщо в архіві радімовника використовується онлайновий сервіс зі зберігання музичних файлів, то до колекції можна отримати доступ 3 будь-якого комп'ютера, що має вихід в інтернет. Не допускається розміщення фонодокументів на підлозі, підвіконнях, в нерозібраних стосах. Всі приміщення архіву радіопідприємства, а також стелажі, шафи, полиці нумеруються. У кожному окремому приміщенні стелажі, шафи, полиці нумеруються зверху вниз, зліва направо.

Практично невирішеною проблемою залишається питання вибору носія для тривалого зберігання в архівах. Взагалі загальний масив систематизується за видами запису фонографічний, грамофонний, шорінофонний, оптичний, магнітний, лазерний. Найчастіше виділяються три групи - фонограми на грамплатівках, магнітних стрічках та оптичних дисках.

Величезне число цінних записів, виконаних на магнітних стрічках старих типів, вимагає термінової реставрації. Особливо складна ситуація склалася в студіях, змушених використовувати стрічку виробництва «Свема» (Україна), яка має властивість відшаровуватися від основи. Якщо завдання реставрації фонограм так чи інакше вирішується, то процес вибору типу носія заводить у глухий кут. Сучасні магнітні плівки при дотриманні певних умов можна зберігати до $50-100$ років.

В архівосховищах, обладнаних системами кондиціонування повітря, підтримується наступний оптимальний температурно-вологісний режим для зберігання звукозаписів на чорнобілих плівкових носіях - температура $+15^{\circ} \mathrm{C}$, відносна вологість повітря 40-55 відсотків, на кольорових плівкових носіях - температура від +2 до $+5^{\circ} \mathrm{C}$, відносна вологість повітря 40-55 відсотків, на електронних носіях - температура від +15 до $+25^{\circ} \mathrm{C}$, відносна вологість повітря 40-60 відсотків. В архівосховищах 3 нерегульованим кліматом здійснюються раціональне опалення, провітрювання будівлі і зволоження (осушення) повітря.

Різкі коливання (сезонні і протягом однієї доби) температури і відносної вологості повітря не допускаються [1, С. 10-18].

В умовах цифровізації радіоархіви поступово переходять на електронні формати зберігання фонодокументів. У літературі існує кілька визначень архіву електронного документу 
організації [12, С. 51-60]. Електронний архів має всі необхідні запобіжники, що гарантують повне збереження інформації впродовж довгого періоду часу. Всі оригінальні документи, що в цифровому вигляді знаходяться на центральному сервері надійно захищені, а користувачі мають доступ тільки до електронних копій. Архів електронних документів організації дозволяє значно оптимізувати та автоматизувати бізнес-процеси сучасного підприємства [5, С. 17-25]. «Типовий порядок здійснення електронного документообігу в органах виконавчої влади», що затверджений Постановою КМУ, встановлює загальні правила документування в органах влади управлінської діяльності в електронній формі і регламентує виконання дій з електронним документом 3 моменту їх створення або одержання до відправлення чи передачі до відповідного архіву. Ми приєднуємося до пропозиції розуміти під архівом електронних документів систему зберігання документів в електронному вигляді, що забезпечує надійність зберігання, конфіденційність, швидкість пошуку і обмін документацією [4, С. 189-191]. Електронні документи можуть зберігатися в архіві організації або в спеціалізованому підрозділі.

Для зберігання електронних документів в межах 5 років цілком надійні будь-які сучасні носії інформації (в тому числі, магнітні дискети). Оптичні диски вважаються найбільш довговічними носіями. Деякі виробники визначають термін зберігання своєї продукції мало не в 200 років.

Наскільки це обгрунтовано, може показати лише практика, а вона вкрай суперечлива. 3 одного боку, є свідчення успішного використання записів на CD протягом $10-15$ років, з іншого боку, регулярно з'являються повідомлення про відмови зчитування інформації з цих дисків [11]. При організації довготривалого зберігання електронних документів цілком допустимий термін в 10 років для зберігання носіїв, на які вони записані. При цьому допустимі «офісні» режими зберігання: для магнітних стрічок - температура $+23^{\circ} \mathrm{C}$ (ISO 18923), для оптичних дисків $-+25^{\circ} \mathrm{C}$ (ISO 18927), при відносній вологості 50\%. «Основні правила роботи державних архівів» встановлюють наступний температурно-вологісний режим в архівосховищах: температура $-+17-19^{\circ} \mathrm{C}$, відносна вологість - 50-55\%. [7]. При таких умовах можна розраховувати на термін зберігання дисків CD-R до 20 років [11].

Архівні звукозаписи розміщуються на стелажах, в металевих шафах горизонтально або вертикально в коробках або інших первинних засобах зберігання (папках, футлярах, тощо). Фонодокументи зберігаються в горизонтальному положенні в металевих або пластикових коробках з отворами в коробках для запобігання накопичення всередині коробки парів оцтової кислоти, що виділяються основою плівки або заводський картонній упаковці на стаціонарних стелажах. Не допускається зберігання архівних документів на носіях з магнітним робочим шаром на феромагнітних металевих стелажах.

Сталеві стелажі можуть бути використані у виняткових випадках, тільки за умови розмагнічування і замикання контурів стелажа. Кожна одиниця зберігання аудіовізуального або електронного документа укладається в негерметичну індивідуальну упаковку. При цьому має бути виключене вільне переміщення архівного документа всередині упаковки. Розстановка засобів зберігання здійснюється відповідно до таких норм: відстань між їх рядами - 120 см; засобами зберігання - 75 см; зовнішньою стіною будівлі і паралельними ій засобами зберігання -75 см; стіною і торцем засобів зберігання - 45 см; підлогою та нижньою полицею засобів зберігання -15 см.

Якщо проблеми фізичного збереження файлів на даний час вирішуються досить успішно, то інші аспекти довготривалого зберігання електронних документів чекають свого методологічного обгрунтування та технологічного прориву. Бажано кожні 10-15 років копіювати документи на нові типи електронних носіїв. Так що питання, чи збережуть свої якості магнітні стрічки або оптичні диски після 50 років зберігання, втрачає гостроту [11].

У короткостроковій перспективі (5-10 років) збереження документів забезпечується створенням резервного і робочого примірників електронних документів на окремих носіях. У довготривалій перспективі (понад 10 років) необхідно проведення міграції документів в так звані програмно незалежні формати (страхові формати), причому таким чином, щоб в подальшому отримане покоління документів можна було визнати оригіналами.

Електронні документи в страхових форматах можуть виявитися дуже незручними у використанні і можуть значно уповільнювати час доступу користувачів до архівної інформації. Оперативність доступу до архівних електронних документів може забезпечуватися тим, що вони будуть прийматися, зберігатися та/або своєчасно перекладатися в формати поточної інформаційної системи організаціі/архіву - призначені для користувача формати. Процедура міграції в призначені для користувача формати також має бути орієнтована на можливе визнання отриманих документів 
оригіналами. Цей захід необхідний у зв'язку з тим, що заздалегідь важко визначити, які з форматів (страхові, призначені для користувача або ті, в яких документи прийняті на зберігання) можуть стати основою для створення міграційних страхових копій наступних поколінь [11, С. 16-29]. Якісні показники магнітного запису досить високі та дозволяють відтворення через 100 років зберігання, а також реставрацію із застосуванням новітніх алгоритмів. Жоден інший звуконосій не володіє такими перевагами. 3 метою закріплення місця зберігання фонодокументів у сховищах складаються топографічні покажчики [8]. Фонодокументи зберігаються в умовах, що виключають пряме попадання світла, і підлягають захисту від агресивних домішок у повітряному середовищі (сірчистого газу, сірководню, парів ртуті, оксидів азоту, аміаку), електромагнітно-іонізаційного (радіаційного) впливу [1, С. 10-18].

Висновки. Розкрито основні принципи та положення щодо зберігання фонодокументів в архівах Національної Суспільної телерадокомпанії України, які знаходяться у приміщенні Центральної дирекції «Українське радіо». 3'ясовано, що облік ведеться як в електронному каталозі, так і в фізичній картотеці на паперових носіях. Встановлено, що один обов'язковий примірник передається на зберігання до фондів Державного кінофотофоноархіву України ім. Г. Пшеничного (згідно із Законами України «Про Національний Архівний фонд» [9], №595$\mathrm{XIV}$ «Про обов’язковий примірник документів» та № 867-V «Про внесення змін до статті 8 Закону України «Про обов'язковий примірник документів»), зберігаючи за УР право власності на них. Описано характеристики наявних сховищ та прийняті для безпечного зберігання інформації температурні та вологісні режими, типи та види носів, масиви інформаційних ресурсів та кількість одиниць зберігання. Описано встановлений на підприємстві порядок видачі та прийняття на зберігання вироблених фонограм, встановлено джерела комплектування фондів.

\section{ЛIТЕРАТУРА}

1. Барабаш Н.С. Ведущий информационно-музыкальной радиостанции - становление профессии, специфика и методы работы: дисс. ... канд. фил. наук 10.01.10. М., 2002. 149 с.

2. Жукова М.М. Телерадиофонд Всероссийской государственной телерадиокомпании: организация комплектования и использования документов (1990-е - 2013 гг.): дисс. ... канд. ист. наук: $05.25 .02-$ Документалистика, документоведение, архивоведение, М.: РГГУ, 2019, 239 с.

3. Журавльова О.А. Створення та діяльність «Радіо Київ» у 1950-х - на початку 1960-х років // Наукові записки Інституту журналістики. Т. 4 (65). 2016. Жовтень-грудень. С. 33-39.

4. Захист архівних зібрань від крадіжок. Звіт до Європейського бюро національних архівів про семінар, що відбувся у Стокгольмі 8-9 вересня 2005 р. // Архіви України. 2005. № 5-6 (258). С. 91-94.

5. Кулешов С. Електронний документ у системі сучасного діловодства // Архіви України, 2004. № 4-6 (255). C. 50-53.

6. Лізанчук В.В. Основи радіожурналістики: підручник / Львівськ. нац. ун-т ім. Івана Франка. Київ: Знання, 2006. $628 \mathrm{c}$.

7. Правила роботи архівних установ України / упоряд.: Л.А. Кисельова, Ю.А. Прилепішева, Т.П. Прись, С.В. Сельченкова; за заг. ред. Н.М. Христової; М-во юстиції України, Держ. архів. служба України. К., 2013. 243 с.

8. Про затвердження Правил організації діловодства та архівного зберігання документів у державних органах, органах місцевого самоврядування, на підприємствах, в установах і організаціях : Наказ Міністерства юстиції України від 18 червня 2015 р. № 1000/5. Зареєстровано в Міністерстві юстиції України 22 червня 2015 p. за № 736/27181. Retrieved from https://vk24.ua/regulations_and_jurisprudence/nakazi/nakaz-ministerstva-usticii-ukraini-pro-zatverdzennapravil-organizacii-dilovodstva-ta-arhivnogo. (доступ 10.03.2021)

9. Про Національний архівний фонд та архівні установи: Закон України від 24.12.1993 р. (редакція зі змінами станом на 16.10.2020р.) // Відомості Верховної Ради України, 1994, № 15, Ст. 86.

10. Сидоренко Т.В., Тягій Є.В. Електронні виставки архівних документів як інформаційний ресурс регіону (на прикладі Державного архіву Миколаївської області) // Бібліотекознавство. Документознавство. Інформологія. 2019. №1. С. 89-96.

11. Тихонов В.И. Архивное хранение электронных документов: проблемы и решения // Делопроизводство и документооборот на предприятии. 2006. № 2. С. 16-29.

12. Тихонов В. И. Задачи архивного хранения электронных документов // Отечественные архивы. 2010. № 3. C. 51-60.

13. Юмашева Ю.Ю. Аудиовизуальные архивы в сети Интернет // Историческая информатика. 2018. № 4. C. 84-110. 